\title{
Short Communication \\ pH decline of the M. longissimus thoracis of night-cropped Grey Duiker (Sylvicapra grimmia)
}

\author{
L.C. Hoffman* and A.V. Ferreria \\ Department of Animal Sciences, University of Stellenbosch, P. Bag X1, Matieland, 7602, South Africa
}

\begin{abstract}
The effect of night cropping (shooting the animal in the head with a light calibre rifle) on the $\mathrm{pH}_{45}, \mathrm{pH}_{24}$ and rate of $\mathrm{pH}$ decline in the M. longissimus thoracis of ten Grey duiker was investigated. A mean $\mathrm{pH}_{45}$ of $6.28 \pm 0.3895$ and a mean $\mathrm{pH}_{24}$ of $5.55 \pm 0.0803$ was recorded. The change in $\mathrm{pH}$ with time was fitted to the exponential function $\mathrm{y}=\mathrm{a}$ $+b \mathrm{e}^{(\mathrm{ct})}$ for the pooled data, and values of $5.5156 \pm 0.06294,0.8387 \pm 0.11184$ and $-0.2281 \pm 0.07311$ were realised for the constants $\mathrm{a}, \mathrm{b}$ and $\mathrm{c}$, respectively. This exponential function indicates that the $\mathrm{pH}$ of duiker meat reaches an asymptotic $\mathrm{pH}$ of 5.52 after $24 \mathrm{hrs}$ under these cropping conditions.
\end{abstract}

Keywords: muscle $\mathrm{pH}$, venison, stress, cropping, Grey duiker

*Author to whom correspondence should be addressed. E-mail: $\underline{\text { lch@land.sun.ac.za }}$

\section{Introduction}

The effect of ante-mortem stress on the meat quality of farmed animal species is well documented. The $\mathrm{pH}$ of meat (initial and final $\mathrm{pH}$, as well as the rate of the $\mathrm{pH}$ decline) is one of the most important indicators of the effect of ante-mortem stress on meat quality (Lawrie, 1998), as meat $\mathrm{pH}$ influences both the colour and the water-binding capacity of muscle. In South Africa, the commercial cropping of wild ungulates for venison consists of shooting the animals either at night or, during daylight, from a helicopter or a hide. Veary (1991) and Lewis et al. (1997) determined night shooting to be the best method for the harvesting of game. It not only causes the least damage and wastage to the carcass, but also results in less stress for the survivors. A head or neck shot normally results in the animals dropping instantly, whilst shoulder or rib shots could result in the animals running substantial distances before dying (Von La Chevallerie \& van Zyl, 1971). The latter is unacceptable because it results in a deterioration of meat quality.

Within South Africa, venison is normally perceived to be a dark unattractive red colour, somewhat similar to beef that has been classified as dark, firm and dry (Scanga et al., 1998). This phenomenon in beef is normally associated with ante-mortem stress, particularly in male animals (Lawrie, 1998). Apart from the work of Veary (1991) and Von La Chevallerie \& van Zyl (1971), little data is available on the effects of cropping /shooting of wild ungulates on the quality of the venison. The results of Veary (1991) and Von La Chevallerie \& van Zyl (1971) indicate that the level of ante-mortem stress has a detrimental effect on meat quality (colour and waterbinding capacity).

\section{Material and methods}

Ten male Grey Duiker (Sylvicapra grimmia) originating from a commercial sheep farm in the Eastern Cape, were shot in the head at night using a .22 calibre rifle according to the method described by Lewis et al. (1997). This consists of driving slowly at night in a vehicle and using a sharp spotlight to find and immobilise the animals when they are shot in the head with a light-calibre rifle fitted with a telescopic sight. After killing, the animals are strung up by their hind legs and immediately exsanguinated. In the present investigation, none of the animals were wounded. After being shot, the $\mathrm{pH}$ values $\left(\mathrm{pH}_{45}\right.$ and $\left.\mathrm{pH}_{24}\right)$ of the M. longissimus thoracis et lumborum were measured using a calibrated hand-held Crison $\mathrm{pH} / \mathrm{mV}-506$ meter, equipped with a glass electrode. The $\mathrm{pH}$ meter was re-calibrated after every reading and the electrode rinsed with distilled water between measurements. The $\mathrm{pH}$ was measured at a point $25 \mathrm{~mm}$ from the midline between the second and third last thoracic vertebrae. The $\mathrm{pH}$ was measured approximately 45 minutes after cropping $\left(\mathrm{pH}_{45}\right)$, and thereafter at 2, 4, 6, 12, 18 and 24 hours $\left(\mathrm{pH}_{24}\right)$ post mortem. 
The non-linear regression procedure (Proc. NLIN) of SAS (1988) was used to fit various regression models for the $\mathrm{pH}$ decline over time. The best model fitted was of the exponential form:

$y=a+b e^{(c t)}$

where $\mathrm{y}$ is the dependant variable $(\mathrm{pH}), \mathrm{t}$ the time $(\mathrm{h})$, and $\mathrm{a}, \mathrm{b}$ and $\mathrm{c}$, the constant values from the above-mentioned model.

\section{Results and discussion}

Results are shown in Table 1. All the duiker with the exception of one showed the expected decrease in pH over time $(c=-0.2281)$. The reason for this exception is not clear, but may be due to the fact that the animal ran approximately $400 \mathrm{~m}$ prior to being cropped (exponential function values: $\mathrm{a}=5.7300 ; \mathrm{b}=-0.3669 ; \mathrm{c}=-0.7336$ ) which may have resulted in depletion of glycogen reserves. The pooled mean $( \pm \mathrm{sd}) \mathrm{pH}_{45}$ was $6.28( \pm 0.3895)$ and $\mathrm{pH}_{24}$ was 5.55 ( \pm 0.0803). Values that are similar to that derived from the exponential function fitted to the data.

Table 1 Mean $\mathrm{pH}$ values and rate of $\mathrm{pH}$ change in the M. longissimus thoracis of cropped common Grey Duiker

\begin{tabular}{|c|c|c|c|c|}
\hline \multirow{2}{*}{\multicolumn{2}{|c|}{$\begin{array}{l}\text { Measured } \mathrm{pH} \\
( \pm \mathrm{sd})\end{array}$}} & \multicolumn{3}{|c|}{ Calculated $\mathrm{pH}( \pm \mathrm{se})$} \\
\hline & & \multicolumn{3}{|c|}{$\begin{array}{l}\text { Constants for the exponential equation: } \\
\mathrm{y}=\mathrm{a}+\mathrm{b} \mathrm{e}^{(\mathrm{ct})}\end{array}$} \\
\hline $\mathrm{pH}_{45}$ & $\mathrm{pH}_{24}$ & $\mathrm{a}$ & $\mathrm{b}$ & $\mathrm{c}$ \\
\hline 6.28 & 5.55 & 5.5156 & 0.8387 & -0.2281 \\
\hline \pm 0.3895 & \pm 0.0803 & \pm 0.06294 & \pm 0.11184 & \pm 0.07311 \\
\hline
\end{tabular}

The regression indicates that the M. longissimus thoracis et lumborum of the duiker has a $\mathrm{pH}$ of 6.34 at time zero, and that it declines at a rate of 0.2281 units per $\mathrm{hr}$ to reach an asymptotic value of 5.52. For helicopter, ground-day and ground-night cropping methods, Veary (1991) noted the following values for $\mathrm{pH}_{0}: 6.16,6.13$ and 6.24 respectively, and 5.67, 6.15 and 5.67 respectively, for $\mathrm{pH}_{48}$ in the M. longissimus thoracis of springbok (Antidorcas marsupialis). In the present investigation, the duiker had higher initial and lower final $\mathrm{pH}$ values compared to that of the springbok. The high variation $(\mathrm{sd}=0.3895)$ in the initial $\mathrm{pH}_{45}$ values of this investigation may be attributed to slight ante-mortem stress of the animals prior to cropping. It did not appear that any of the animals were abnormally stressed (with the exception of the animal mentioned); however, these small animals are found in thickets where they may have noticed the hunting vehicle before they themselves were noted and may have taken avoidance action. This normally consists of sudden bursts of running and diving through bushes; an activity that could have reduced muscle glycogen reserves (Scanga et al., 1998).

The results of this study suggest that cropping of duiker according to the methods described by Lewis $e t$ al. (1997) does not adversely affect meat quality in terms of the rate of $\mathrm{pH}$ decline. Further investigations into the effect of night cropping on other species and on different meat-quality parameters need to be examined.

\section{References}

Lawrie, R.A., 1998. Lawrie's Meat Science. Woodhead Publ. Ltd., Cambridge.

Lewis, A.R., Pinchin, A.M. \& Kestin, S.C., 1997. Welfare implications of the night shooting of wild Impala (Aepyceros melampus). Animal Welfare 6: 123.

SAS, 1988. SAS/STAT User's Guide, Release 6.03. SAS Institute Inc., Cary, NC.

Scanga, J.A., Belk, K.E., Tatum, J.D., Grandin, T. \& Smith, G.C., 1998. Factors contributing to the incidence of dark cutting beef. J. Anim. Sci. 76: 2040.

Veary, C.M., 1991. The effect of three slaughter methods and ambient temperature on the $\mathrm{pH}$ and temperatures in springbok (Antidorcus marsupialis) meat. M.Med.Vet(Hyg) thesis. Faculty of Veterinary Science, University of Pretoria, South Africa.

Von La Chevallerie, M. \& Van Zyl, J.H.M., 1971. Some effects of shooting losses of meat and meat quality in springbok and impala. S. Afr. J. Anim. Sci. 1: 113. 